\title{
MADRASAH DAN PERTUMBUHAN ILMU-ILMU ISLAM
}

\section{MADRASAH AND THE GROWTH OF ISLAMIC SCIENCES}

\author{
Suriyati1), R. Nurhayati2), Muh. Judrah' ${ }^{3)}$, Agus Suwito ${ }^{4}$ \\ 1,2,3,4)Institut Agama Islam Muhammadiyah Sinjai \\ suriyati.iaim@gmail.com ${ }^{11}$, nurhayati1984@gmail.com ${ }^{2}$, muh.judrah68@gmail.com³), \\ aguswito@iaimsinjai.ac.id4)
}

\begin{abstract}
Abstrak
Artikel ini bertujuan untuk membahas sejarah dan perkembangan madrasah di Indonesia serta peran/fungsi madrasah dalam mentransmisikan ilmu-ilmu Islam. Tulisan ini disusun dengan pendekatan kualitatif dan jenis penelitian kepustakaan (library research). Teknik pengumpulan dan sumber data dan menggunakan dokumentasi yang berasal dari buku, jurnal dan referensi yang relevan dengan fokus kajian. Sementara instrumen pengumpulan data adalah peneliti sendiri (human instrument). Analisis data yang digunakan berupa analisis isi atau content analysis yang mengurai tentang fokus kajian. Kesimpulannya adalah dalam sejarahnya, Lembaga madrasah sesungguhnya bukanlah lembaga pendidikan Islam asli di Indonesia, akan tetapi berasal dari negara Islam di bagian Timur Tengah yang berkembang sekitar abad ke-10 M atau $11 \mathrm{M}$. Keberadaan lembaga madrasah dalam pendidikan Islam turut mewarnai pengembangan ilmu pengetahuan Islam. Dalam hal ini terbukti dari banyaknya ilmu pengetahuan yang berkembang baik yang dikembangkan pada masa Dinasti Umayyah maupun Dinasti Abbasiyah. Ada madrasah yang mengkhususkan diri untuk mempelajari satu disiplin ilmuilmu tertentu, misalnya madrasah nahwu, madrasah tafsir atau madrasah hadits yang pada gilirannya membawa perkembangan pada ilmu-ilmu tersebut.
\end{abstract}

Kata Kunci: madrasah, ilmu-ilmu Islam

\begin{abstract}
This article aims to discuss the history and development of madrasah in Indonesia and the role/function of madrasah in transmitting Islamic sciences. This paper is structured with a qualitative approach and the type of library research. Data collection techniques and sources use documentation from books, journals and references relevant to the focus of the study. While the data collection instrument is the researcher himself (human instrument). The data analysis used is in the form of content analysis which describes the focus of the study. The conclusion is that in its history, madrasa institutions were not actually original Islamic educational institutions in Indonesia, but originated from an Islamic country in the Middle East which developed around the 10th or 11th century AD. In this case, it is evident from the large number of developed knowledge that was developed during the Umayyad and Abbasid dynasties. There are madrasah that specialize in studying one particular discipline, for example the nahwu madrasah, the tafseer madrasah or the hadith madrasah which in turn lead to developments in these sciences.
\end{abstract}

Keywords: madrasah, Islamic sciences

How to Cite: Suriyati, Nurhayati, R., Judrah, M., \& Suwito, A. (2021). Madrasah dan pertumbuhan ilmu-ilmu Islam. Al asma: Journal of Islamic Education, 3(1), 167-174. 


\section{PENDAHULUAN}

Membicarakan sejarah pertumbuhan ilmu-ilmu Islam dalam konteks yang sebenarnya, dapat dilihat sejak dimulainya dakwah nabi Muhammad saw secara resmi di Mekkah, konsentrasi dakwah beliau seperti diketahui pengajaran tentang tauhid, ibadah dan akhlah. Sejak awal Nabi Muhammad saw tidak memperkenalkan ilmu-ilmu dalam bentuk dikotomis (dibedakan) sebab sumber ilmu lainya hanya satu yaitu Allah al-Aliim Tuhan Yang Maha Tahu), sedangkan Ilmu-ilmu aqliah profan belum begitu dibutuhkan karena posisi ilmu tersebut hanya sebagai pelengkap dan penunjang perkembangan dalam menuntut ilmu pada zaman sekarang lebih modern dibandingkan dengan keadaan pada zaman dahulu. Bahkan proses belajar mengajarnya sangat berbeda sekali. Pada zaman sekarang dimanapun kita bisa belajar karena adanya kemajuan tekhnologi, Pertumbuhan ilmu ilmu Islam di zaman modern ini sangat berbeda dengan zaman dahulu dan proses pembelajarannya pun berbeda kalau zaman dahulu proses pendidikan diadakan di rumahrumah sahabat tertentu dan yang paling terdekat dengan Darul Al Arqom (Al-Arqam bin Abi al-Arqam bi As'ad ,Al-makhzumi ra, 2020).

Lembaga madrasah adalah inovasi kelembagaan dalam sejarah pendidikan Islam (Islamiyah, 2015). Madrasah-madrasah yang paling awal muncul di wilayah khurasan, Persia pada abad ke 4/10 (Hasan Asari, 2018: 17). Akan tetapi, lembaga madrasah menjadi fenomenal pada abad berikutnya, terutama setelah wazir Dinasti Saljuk, Nizam AlMulk membangun sejumlah madrasah di hamper semua kota penting wilayah Saljuk. Salah satu buku yang membahas sejarah madrasah dalam jumlah besar adalah Al-Daris fi Tarikh al-Madaris karya al Nu'yami. Tampaknya, inovasi lembaga madrasah bersumber pada lembaga masjid. Munculnya masjid-khan, yaitu masjid yang menyediakan penginapan atau asrama bagi penuntut ilmu, adalah merupakan tahapan tradisi. Dengan demikian dapat disimpulkan bahwa istilah lembaga madrasah bersumber dari Islam itu sendiri. Dalam perkembangannya di Indonesia, madrasah islamiyah ini merupakan lembaga yang berdiri jauh sebelum SD, SMP sederajat, SMU sederajat atau perguruan tinggi sebab madrasah adalah salah satu sarana atau media tempat yang strategis bagi kiyai/ustad dengan masyarakat dalam rangka menyampaikan pada aspek ajaran Islam. Melalui madrasah juga, dan para raja muslim menyampaikan program kenegaraan dan keagamaan yang dianutnya itu.

Lembaga madrasah sesungguhnya bukanlah lembaga pendidikan Islam asli di Indonesia, akan tetapi berasal dari negara Islam di bagian Timur Tengah yang berkembang sekitar abad ke-10 $\mathrm{M}$ atau $11 \mathrm{M}$. Lembaga pendidikan madrasah berkembang sebagai simbol para golongan orang sunni. Lembaga madrasah didirikan adalah sebagai sarana transmisi pada ajaran-ajaran golongan orang-orang sunni. Perkembangan berikutnya, lembaga madrasah merupakan lembaga pendidikan Islam formal seperti halaqah, surau atau masjid. Seluruh dunia atau negara Islam telah mengadopsi sistem lembaga madrasah, di samping kuttab, surau dan masjid untuk mentransmisi nilai-nilai Islam. Pada awal perkembangannya lembaga madrasah tergolong lembaga pendidikan setingkat college (jika dibandingkan dengan lembaga pendidikan Islam saat ini.

Di Indonesia istilah "lembaga madrasah" diadopsi untuk memenuhi kebutuhan modernisasi di lembaga pendidikan islam dengan menggunakan sistem tradisional, perjenjangan, penggunaan dibangku, bahkan memasukan pengetahuan umum di dalamnya sebagai bagian kurikulumnya. Menurut Asrohah (1999) Lembaga madrasah di 
Indonesia muncul sebagai jembatan yang menghubungkan antara lembaga pendidikan umum dan lembaga pendidikan tradisional yaitu lembaga lembaga pesantren. Lembaga madrasah menawarkan lembaga pendidikan umum sebagai mana ditawarkan sekolah umum. Dapat dikatakan bahwa lembaga madrasah pada awal abad ke -20 sudah mengalami konsolidasi sebagai lembaga pendidikan Islam modern (Subhan, 2012).

Oleh karena itu, tulisan ini dibuat dengan dasar untuk mengetahui lebih jelas dan lebih rinci gambaran lembaga pendidikan madrasah dan ilmu-ilmu islam. Oleh karena itu, tulisan ini bertujuan untuk mendeskripsikan: (1) sejarah dan perkembangan madrasah di Indonesia; dan (2) peran/fungsi madrasah dalam mentransmisikan ilmu-ilmu Islam.

\section{METODE PENELITIAN}

Tulisan ini disusun dengan menggunakan pendekatan penelitian kualitatif dan jenis penelitian kepustakaan (library research) yang berfokus pada lembaga madrasah dan pertumbuhan ilmu-ilmu Islam. Teknik pengumpulan dan sumber data menggunakan dokumentasi yang berasal dari buku, jurnal dan referensi-referensi yang relevan dengan fokus kajian, sementara instrumen pengumpulan data adalah peneliti sendiri (human instrument). Analisis data yang digunakan berupa analisis isi atau content analysis yang mengurai tentang fokus kajian.

\section{HASIL DAN PEMBAHASAN}

Pengertian Madrasah

Dalam kamus besar bahasa Indonesia madrasah adalah sekolah atau perguruan yang biasanya berdasarkan agama Islam (Tim Penyusun Kamus Pusat Pembinaan dan Pengembangan Bahasa, 1989). Madrasah juga dapat dinilai berasal dari istilah al-Madãris, suatu istilah yang digunakan oleh para Fuqãha (Ulama ahli Fiqih), sehingga pada masa kekhalifahan Abbasiyyah, madrasah dianggap sebagai tradisi sistem pendidikan bercorak fiqh dan Hadits (Maksum, 1999).

Di Indonesia, peraturan Menteri Agama RI No. 1/1946 dan No.7/1950 memformulasikan madrasah sebagai berikut:

1. Tempat lembaga pendidikan yang diatur sebagai sekolah dan membuat pendidikan dan ilmu pengetahuan agama Islam menjadi pokok pengajaran.

2. Pondok pesantren yang dapat memberikan pendidikan setingkat dengan madrasah (sekolah) (Tim Dirjen Bimbagais Depag, 2003).

\section{Sejarah dan Perkembangan Madrasah di Indonesia}

Istilah "madrasah atau lembaga pendidikan islam" juga diadopsi oleh umat Islam di Negara Indonesia. Di bagian Timur Tengah lembaga madrasah merupakan lembaga pendidikan Islam tradisional akan tetatpi bisa berkembanga menjadi modern seseui zamanya tanpa mengurangi konten dari lembaga madrasah itu sendiri, seperti surau, dayah, atau pondok pesantren yang tidak mengenal sistem klasikal dan penjenjangan. (Sulasteri, 2016). Akan tetapi, kehadiran lembaga madrasah di negara Indonesia menunjukkan fenomena modern dalam sistem lembaga pendidikan Islam.

Mendirikan lembaga madrasah ini awalnya dilatarbelakangi sebagai upaya pemerintah dalam memformalkan sistem pendidikan informal yang sudah ada sebelumnya. Dengan demikian, pemerintah dapat memiliki keterlibatan yang lebih jelas 
terhadap pemberlakuan ketentuan terhadap komponen-komponen pendidikan yang ada di lembaga madrasah. Munculnya madrasah sebagai lembaga pendidikan Islam ini dipicu oleh kekhawatiran dari umat Islam di Indonesia terhadap pemerintah Hindia-Belanda yang mendirikan sekolah-sekolah umum tanpa mengikutsertakan pendidikan Islam di dalam kurikulumnya. Lembaga pendidikan Islam di Indonesia telah ada sejak zaman kerajaan Islam. Pondok pesantren merupakan lembaga pendidikan Islam yang telah berkembang sejak zaman kolonial. Pada awalnya semua pesantren hanya mengajarkan ilmu agama, karena mendirikan madrasah (Steenbrink, 1994). Kelahiran perkembangan pemikiran masyarakat Islam, ada kalangan umat Islam yang merasa tidak puas dengan sistem pesantren maka sejarah dan perkembangan lembaga madrasah dibagi dalam dua periode yaitu:

a. Periode Sebelum Kemerdekaan

Pendidikan dan pengajaran pendidikan agama Islam dalam bentuk pengajian AlQur'an dan pengajian kitab yang diselenggarakan di rumah, surau, masjid, lembaga pesantren, dan lain-lain. Pada perkembangan selanjutnya mengalami perubahan bentuk baik dari segi lembaganya, materi pengajarannya ataupun kurikulum, metode maupun struktur organisasinya sehingga dapat melahirkan suatu bentuk baru yang disebut lembaga madrasah. Pendidikan Islam merupakan sebuah trans-internalisasi ilmu pengetahuan dan nilai-nilai keIslaman melalui upaya pembelajaran, pembiasaan pengawasan dan pengembangan potensi peserta didik untuk kehidupan yang baik di dunia dan akhirat (Mujib \& Madkur, 2016).

Lembaga pendidikan madrasah sebagai lembaga pendidikan Islam berfungsi menghubungkan sistem lama dengan sistem yang baru dengan jalan mempertahankan nilai-nilai lama yang masih baik yang dan masih dapat dipertahankan dan mengambil sesuatu yang baru dalam ilmu, terknologi dan ekonomi yang dapat bermanfaat bagi kehidupan umat Islam. Oleh karena itu, isi kurikulum lembaga madrasah pada umumnya adalah apa yang diajarkan di lembaga-lembaga pendidikan Islam (surau dan pesantren) ditambah dengan beberapa materi pelajaran yang disebut dengan ilmu-ilmu umum.atau ilmu sains

Latar belakang pertumbuhan lembaga madrasah di Indonesia dapat dikembalikan pada dua situasi penting, yaitu:

1. Gerakan pembaharuan Islam di Indonesia, muncul pada awal abad ke-20 yang dilatarbelakangi oleh kesadaran dan semangat yang kompleks sebagaimana diuraikan oleh Karel A Steenbrink dengan mengidentifikasi empat faktor yang mendorong gerakan pembaharuan Islam di negara Indonesia, adalah:

a. Kemauan untuk kembali berpedoman kepada Al-Qur'an dan hadis

b. Semangat nasionalisme dalam melawan penjajah yang terjadi

c. Memperkuat basis gerakan sosial, ekonomi, budaya dan politik

d. Pembaharuan system pendidikan Islam di Indonesia

Bagi tokoh-tokoh pembaharuan islam, pendidikan Islam kiranya senantiasa dianggap sebagai aspek yang strategis untuk membentuk sikap, moral, akhlak dan pandangan keislaman masyarakat. Oleh karena itu, pemunculan lembaga madrasah tidak bisa lepas dari gerakan pembaharuan Islam yang dimulai oleh usaha beberapa orang tokoh-tokoh intelektual agama Islam yang selanjutnya dikembangkan oleh organisasiorganisasi Islam. 
2. Respons lembaga pendidikan Islam terhadap kebijakan pendidikan di negara Hindia Belanda pertama kali bangsa Belanda datang ke Nusantara hanya untuk kegiatan berdagang, tetapi karena kekayaan alam Nusantara yang sangat banyak, maka tujuan utama untuk berdagang berubah untuk menguasai wilayah Nusantara dan menanamkan pengaruh di Nusantara sekaligus dengan mengembangkan pahamnya itu yang terkenal dengan semboyan 3G yaitu, Glory, Gold, dan Gospel.

b. Periode sesudah kemerdekaan

Setelah kemerdekaan bangsa Indonesia tanggal 17 Agustus 1945, kemudian pada tangal 3 Januari 1946 dibentuklah Departemen Agama yang akan mengurus keberagamaan di Indonesia termasuk didalamnya lembaga pendidikan, khususnya lembaga madrasah. Secara instansional, Departemen Agama diberikan kewajiban dan bertangung jawab terhadap pembinaan dan pengembangan pendidikan agama dalam lembaga-lembaga tersebut. Lembaga-lembaga pendidikan agam Islam ada yang berstatus negeri ada yang berstatus swasta.

Dalam upaya meningkatkan lembaga madrasah, maka pemerintah melalui Kementerian Agama memberikan bantuan dalam bentuk material dan bimbingan, untuk itu Kementerian Agama mengeluarkan peraturan Menteri Agama No 1 Tahun 1946 dan disempurnakan dengan peraturan Menteri Agama No 7 Tahun 1952. Di dalam peraturan tersebut, terdapat ketentuan jenjang pendidikan pada lembaga madrasah yang terdiri dari lembaga madrasah rendah (MI), lembaga madrasah pertama (MTs), lembaga madrasah lanjutan atas (MA).

Upaya pemerintah selanjutnya untuk meningkatkan status lembaga madrasah adalah dengan jalan menegerikan lembaga madrasah-madrasah swasta yang dikelola oleh masyarakat, baik yang berbentuk pribadi ataupun organisasi. Tercatat sejumlah ratusan lembaga madrasah swasta yang dijadikan negeri yang meliputi:

1. Lembaga madrasah Ibtidaiyah Negeri MI

2. Lembaga madrasah Tsanawiyah Agama Islam Negeri Mts

3. Lembaga madrasah Aliyah Agama Islam Negeri MA. (Daulay, 2012).

Walaupun pendidikan Islam sudah berjalan lama dan mempunyai sejarah panjang. Namun dirasakan, pendidikan Islam masih tersisih dari sistem pendidikan nasional. Keadaan ini berlangsung sampai dikeluarkannya SKB 3 Mentri (Menteri Agama, Pendidikan dan Kebudayaan) pada tanggal 24 Maret 1975 yang berusaha mengembalikan ketertinggalan lembaga pendidikan Islam untuk memasuki mainstream pendidikan nasional. Kebijakan ini membawa pengaruh yang sangat besar bagi lembaga madrasah, karena pertama, ijazah dapat mempunyai nilai yang sama dengan sekolah umum yang sederajat. Kedua, lulusan sekolah madrasah dapat melanjutkan ke sekolah umum yang setingkat lebih tinggi. Ketiga, peserta didik di lembaga madrasah dapat pindah ke sekolah umum yang setingkat (Nizar, 2003).

\section{Fungsi Madrasah dalam Mentransmisikan Ilmu Pengetahuan Agama}

Lembaga madrasah dipandang sebagai lembaga yang khusus mentransmisikan ilmu-ilmu agama dengan memberikan penekanan khusus pada bidang-bidang fiqih, tafsir, dan Al-hadits dan tidak memasukkan ilmu-ilmu umum dalam kurikulumnya. Hal ini disebabkan karena ada 3 alasan, yaitu: 
1. Ini berkaitan dengan pandangan tentang ketinggian ilmu-ilmu keagamaan (al-'uluum ad-diniyyah) yang danggap mempunyai supremasi yang lebih dan merupakan jalan yang mulus menuju Tuhan.

2. Secara institusi lembaga madrasah memang dikuasai oleh mereka yang ahli dalam bidang agama.

3. Berkenaan dengan kenyataan bahwa hampir semua lembaga madrasah didirikan dan dipertahankan dengan dana wakaf dari penguasa politik Muslim atau dermawan karena didorong adanya motivasi kesalehan (Azyumardi, 1999).

Lembaga madrasah dapat diterima di kalangan masyarakat banyak karena kurikulum yang fokus dalam bidang keagamaan, seperti mata pelajaran fiqih misalnya dianggap dapat memenuhi kebutuhan masyarakat dan dapat diberikan pada anggota masyarakat dalam segala tingkatan umur. Di samping itu pula karena pengajar lembaga madrasah adalah para ulama yang notabene merupakan panutan masyarakat serta pembela kepentingan mereka dan memiliki keududukan khusus dalam pemerintahan (Maksum, 1999).

Dapat disimpulkan bahwa lembaga madrasah memiliki fungsi dan peran yang besar dalam mentransmisikan ilmu pengetahuan Islam. Ada beberapa jenis pentranmisiannya, antara lain:

a. Ilmu pengetahuan yang ditransminsikan lembaga madrasah

Para ahli telah banyak melaksanakan penelitian terkait hal ini, bahwa ilmu-ilmu yang ditransmisikan oleh lembaga madrasah adalah Al-Qur'an dan tafsirnya, hadits dan ilmu haditsnya, fiqih dan ushul fiqihnya, ilmu kalam dan bahasa Arab yang meliputi nahwu, sharaf, balaghah sebagai penunjangnya.

b. Cara lembaga madrasah mentransmisikan ilmu pengetahuan islam

Di antara lembaga madrasah yang cukup populer di masanya yaitu lembaga madrasah Nizhamiyah. Cara lembaga madrasah ini mentransmisikan ilmu pengetahuan Islam, yaitu dengan menyelenggarakan tes. Namun peranan pada pendidik masih sangat mendominasi oleh karena besarnya pengaruh pendidik secara perorangan. Misalnya, ijazah yang seharusnya dikeluarkan atas nama lembaga madrasah, tapi dikeluarkan atas nama pendidik. Akan tetapi, dalam hal ini bukan berarti bahwa madrasah tidak mempunyai fungsi strategi terhadap tansmisi ilmu.

Seperti yang disampaikan oleh Fazlur Rahman bahwa mayoritas ulama termasyhur pada awal abad pertengahan bukan produk lembaga madrasah melainkan alumni pada murid-murid informal dari pendidik individual yang tidak dapat dibenarkan semuanya, sebab besar kemungkinan pengkajian disiplin ilmu yang dilakukan antara peserta didik dengan syaikhnya di luar jam pelajaran ini juga boleh jadi dimasukkan ke dalam bagian kegiatan secara keseluruhan (Rahman, 1992).

Adapun alur transmisi ilmu pengetahuan di madrasah secara umum dapat dibagi menjadi 2 bagian, yaitu:

1) Transmisi lewat lisan

Dunia pendidikan Islam zaman klasik berkeyakinan bahwa belajar kepada syaikh secara pribadi dan langsung mendengar uraian (bayan) dari syaikh tidak hanya membaca karya-karya tulisnya dapat dianggap sebagai metode transmisi yang paling baik. Seorang peserta didik tidak dianggap cukup hanya membaca teks karya pendidiknya sendiri. 
Metode ini dilaksanakan dengan cara pendidik membaca teks kemudian mensyarahnya dan peserta didik mendengarkan dan menyimak dengan saksama.

2) Transmisi lewat tulisan

Upaya transmisi lewat tulisan ini dilakukan karena pada masa itu harga kitab/buku sangat mahal, sehingga seorang peserta didik yang berkeinginan memiliki sebuah buku/kitab maka tidak ada jalan lain kecuali ia harus menyalin dari kitab gurunya. Usaha keras ini menjadi alasan dan bukti akan adanya transmisi ilmu pengetahuan lewat tulisan.

\section{SIMPULAN}

Keberadaan lembaga madrasah dalam pendidikan Islam turut mewarnai pengembangan ilmu pengetahuan Islam. Dalam hal ini terbukti dari banyaknya ilmu pengetahuan yang berkembang baik yang dikembangkan pada masa Dinasti Umayyah maupun Dinasti Abbasiyah. Ada madrasah yang mengkhususkan diri untuk mempelajari satu disiplin ilmu-ilmu tertentu, misalnya madrasah nahwu, madrasah tafsir atau madrasah hadits yang pada gilirannya membawa perkembangan pada ilmu-ilmu tersebut. Dengan demikian, madrasah merupakan media atau tempat untuk pengembangan ilmu pengetahuan Islam. Para alumni yang dihasilkan madrasah turut pula menjadikan ilmu pengetahuan Islam berkembang. Mereka mengembangkan ilmu-ilmu tersebut dalam karirnya di berbagai lembaga pendidikan maupun kehidupan bermasyarakat.

Madrasah menjadi wadah utama dalam transmisi ilmu pengetahuan dalam peradaban Islam, meskipun belum menggunakan nama madarasah. Ini terlihat dengan adanya beberapa lembaga pendidikan seperti maktabah, masjid dan lain-lain yang berfungsi sama seperti madrasah, transmisi ilmu pengetahuan dalam peradaban Islam dimulai dengan dialog antara peradaban Islam dengan peradaban lain seperti Yunani (Persia), Aleksandria (Mesir), inilah yang menjadikan proses tranmirasi menjadi lebih berkembang.

\section{DAFTAR PUSTAKA}

Asrohah, H. (1999). Sejarah pendidikan islam. Jakarta: Logos Wacana Ilmu.

Azyumardi, A. (1999). Pendidikan Islam; Tradisi dan Modernisasi Menuju Milenium Baru. Jakarta: Logos.

Daulay, H. P. (2012). Pendidikan Islam dalam sistem pendidikan nasional di Indonesia. Jakarta: Kencana Prenada Media Group.

Islamiyah. (2015). Inovasi pembelajaran pendidikan Islam di madrasah ibtidaiyah. Skripsi, Program Magister IAIN Salatiga.

Maksum. (1999). Madrasah, sejarah dan perkembangannya. Jakarta: Logos Wacana Ilmu.

Mujib, A., \& Madkur, A. (2016). Life skill education on state vocational high schools in metro. Makalah disampaikan di The First International Conference on Law, Economics and Education. Metro: Universitas Muhammadiyah Metro.

Nizar, S. (2003). Sejarah pendidikan Islam. Jakarta: Kencana Prenada Media Group.

Rahman, F. (1992). Islam, terjemah senoaji saleh. Jakarta: Kencana Prenada Media Group.

Steenbrink, K. (1994). Pesantren madrasah sekolah : pendidikan islam dalam kurun modern. Jakarta: LP3ES. 
Subhan, A. (2012). Lembaga pendidikan Islam Indonesia abad ke-20. Jakarta: Kencana.

Sulasteri, T. (2016). Fungsi madrasah dalam pengembangan ilmu pengetahuan Islam. QATRHUNA, 1(1), 1-10.

Tim Dirjen Bimbagais Depag. (2003). Pola Pengembangan pondok pesantren. Jakarta: Direktorat Jenderal Kelembagaan Agama Islam Departemen Agama RI.

Tim Penyusun Kamus Pusat Pembinaan dan Pengembangan Bahasa. (1989). Kamus Besar Bahasa Indonesia. Jakarta: Balai Pustaka. 